\title{
Pengaruh Metode Pembelajaran Tutor Sebaya dan Motivasi terhadap Hasil Belajar Teknologi Informasi dan Komunikasi Siswa
}

\author{
Novidianti $^{1 *}$ Fahmi Rizal $^{2}$, Usmeldi ${ }^{3}$ \\ 1,2,3 Universitas Negeri Padang, Padang, Indonesia \\ *Corresponding author: novidianti88@gmail.com
}

\section{iD}

\author{
-
}

\begin{abstract}
Abstrak
Penelitian ini bertujuan untuk menganalisis pengaruh strategi belajar tutor sebaya dan motivasi terhadap hasil belajar Teknologi Informasi Dan Komunikasi siswa kelas XII SMA. Jenis penelitian ini adalah eksperimen semu. Desain penelitian yang digunakan adalah desain faktorial 2x2. Populasi dalam penelitian ini adalah seluruh siswa kelas XII IPA SMA yang berjumlah 123 orang. Teknik pengambilan sampel pada penelitian ini dilakukan dengan menggunakan teknik cluster sampling. Instrumen yang digunakan adalah angket tertutup untuk mengukur variabel motivasi belajar dan tes objektif untuk mengukur hasil belajar. Uji hipotesis menggunakan analisis komparasi dua kelompok data. Berdasarkan hasil penelitian diketahui bahwa hasil belajar TIK siswa yang diajar menggunakan metode tutor sebaya lebih tinggi dibandingkan dengan menggunakan metode ceramah. Perbedaan hasil belajar antara siswa terlihat dari nilai rata-rata hasil belajar kedua kelas. Hasil belajar TIK siswa yang memiliki motivasi belajar tinggi lebih tinggi dibandingkan dengan siswa yang memiliki motivasi rendah. Perbedaan hasil belajar antara siswa yang memiliki motivasi belajar tinggi dengan siswa yang memiliki motivasi belajar rendah terlihat dari nilai rata-rata hasil belajar kedua kelompok. Pada kelompok siswa dengan motivasi belajar tinggi mendapat nilai rata - rata hasil belajar tidak terdapat interaksi antara metode mengajar dengan motivasi belajar dalam mempengaruhi hasil belajar.
\end{abstract}

Kata kunci: Metode Tutor Sebaya, Motivasi Belajar

\section{Abstract}

This study aims to analyze the effect of peer tutor learning strategies and motivation on learning outcomes of Information and Communication Technology students of class XII SMA. This type of research is a quasi-experimental. The research design used is a $2 \times 2$ factorial design. The population in this study were all students of class XII IPA SMA, amounting to 123 people. The sampling technique in this study was carried out using a cluster sampling technique. The instrument used was a closed questionnaire to measure learning motivation variables and objective tests to measure learning outcomes. Hypothesis testing using comparative analysis of two groups of data. Based on the results of the study, it is known that the ICT learning outcomes of students who are taught using the peer tutoring method are higher than those using the lecture method. The difference in learning outcomes between students can be seen from the average value of the learning outcomes of the two classes. ICT learning outcomes of students who have high learning motivation are higher than students who have low motivation. The difference in learning outcomes between students who have high learning motivation and students who have low learning motivation can be seen from the average value of the learning outcomes of the two groups. In the group of students with high learning motivation got the average value of learning outcomes there was no interaction between teaching methods and learning motivation in influencing learning outcomes.

Keywords: Peer Tutor Methods, Learning Motivation

$\begin{array}{ll}\text { History: } & \text { Publisher: Undiksha Press } \\ \text { Received }: 12 \text { Desember } 2020 & \text { Licensed: This work is licensed under } \\ \text { Revised }: 17 \text { Februari } 2021 & \text { a Creative Commons Attribution 4.0 License } \\ \text { Accepted : } 4 \text { Maret } 2021 & \text { CC } \\ \text { Published : } 25 \text { Maret } 2021 & \text { SA }\end{array}$




\section{Pendahuluan}

Pendidikan yang bermutu adalah pendidikan yang menghasilkan lulusan yang memiliki kemampuan yang mencakup tiga aspek, yaitu aspek kognitif, aspek afektif, dan aspek psikomotorik sehinggga dapat mengikuti berbagai pembaharuan dalam pendidikan (Wendi, 2020). Upaya peningkatan mutu pendidikan memerlukan upaya peningkatan kuallitas pembelajaran (instuctional qualitity), usaha meningkatan kualitas pendidikan tidak akan tercapai tanpa adanya upaya peningkatan kualitas pembelajaran. Untuk mewujudkan pembaruan bidang pendidikan salah satunya dapat dilakukan melalui pembaruan strategi atau metode pembelajaran berbasis teknologi (Aka, 2017).

Mata pelajaran Teknologi Informasi dan Komunikasi (TIK) merupakan mata pelajaran yang menuntut tersedianya sumber belajar yang cukup, tidak hanya sumber belajar yang berupa lingkungan fisik seperti sarana dan prasarana yang memadai dan tetap sumber daya manusia juga (Lestari et al., 2020). Pelajaran TIK pada kurikulum 2013, TIK terintegrasi dalam semua mata pelajaran. Untuk itu pembelajaran TIK penting sangat diperlukan. Mata dipelajari untuk memudahkan siswa'dalam memperoleh dan mengolah informasi agar dapat menunjang pelajaran yang lain (Kurniawan, 2019; Patmanthara, 2018). Pelaksanaan pelajaran TIK menuntut guru berperan sebagai fasilitator dalam membimbing siswa untuk memahami konsep-konsep teknologi informasi dan komunikasi, dalam hal ini guru harus memiliki variasi penggunaan metode pembelajaran yang berpusat pada siswa (student centre) agar siswa lebih aktif dalam proses pembelajaran, oleh sebab itu dibutuhkan metode pembelajaran yang tepat dalam rangka mencapai tujuan pembelajaran secara tuntas (Rivalina, 2014).

Namun, kenyataannya hasil belajar TIK siswa masih banyak yang belum tuntas atau belum mencapai KKM. Hal ini dapat dilihat dari nilai harian semester genap tahun pelajaran 2013/2014 yang dimiliki siswa kelas XI SMAN I X Koto Singkarak. Artinya, hampir sebagian siswa tidak berhasil mencapai kelulusan pada mata pelajaran tersebut. Dari Tabel 1.1 dapat dapat diketahui hasil belajar mata pelajaran TIK kelas XI SMAN 1 X Koto Singkarak pada semester genap tahun pelajaran 2013/2014 dari 207 siswa, 81 orang siswa atau $39 \%$ tidak tuntas atau belum mencapai KKM ( nilai 75), sedangkan 126 orang siswanya atau $61 \%$ siswa nilai ulangan harian siswanya sudah mencapai KKM. Banyaknya jumlah siswa yang belum tuntas atau belum mencapai KKM menunjukkan hasil belajar Teknologi Informasi dan Komunikasi masih rendah dan perlu perbaikan lagi untuk mencapai keberhasilan hasil belajar.

Berdasarkan pengamatan terlihat penyebab rendahnya hasil belajar TIK karena masih rendahnya motivasi belajar siswa, gejala ini nampak dari kehadiran siswa dikelas atau dilabor computer masih banyak siswa yang terlambat masuk. Pada proses pembelajaran berlangsung masih banyak siswa yang keluar minta izin dengan berbagai alasan. Selain itu, masih terdapat siswa di kelas yang main-main dan mengerjakan yang lain di luar materi pelajaran. Permasalahan lain yang diduga menyebabkan rendahnya hasil belajar siswa adalah rendahnya partisipasi siswa dalam belajar, pembelajaran masih berpusat pada guru, media dan sarana belajar (komputer) masih belum lengkap atau tidak memadai, kurangnya waktu guru untuk membimbing siswa secara individu serta karena kurang dimanfaatkannya fasilitas belajar siswa seperti buku, LKPD. Hal ini diduga juga dapat melemahkan semangat dan minta siswa untuk belajar.

Salah satu karakteristik mata pelajaran TIK adalah pembelajaran komputer yang bersifat individual, sehingga menuntut guru dapat membimbing siswa satu per satu (Rivalina, 2014). Hal tersebut tentu sangatlah sulit mengingat keterbatasan guru dalam mendatangi siswa satu persatu yang dapat menimbulkan kelelahan bagi guru karna mengajar beberapa kelas dalam sehari, sehingga guru tidak bertenaga lagi untuk menajar pada kelas berikutnya. Disamping keterbatasan guru dalam menjangkau siswa jumlah komputer juga tidak memadai 
dalam memenuhi kebutuhan siswa, dimana siswa perkelas berjumlah 30-35 siswa sedangkan komputer yang bisa digunakan siswa hanya berjumlah 22 unit dan waktu tatap muka yang tersedia hanya 2 jam pelajaran $(2 \times 45$ menit) untuk teori dan praktek sehingga menimbulkan permasalahan dalam menyelesaikan tugas atau latihan. Permasalahan lain yang terjadi dalam proses pembelajaran TIK adalah kurangnya strategi pembelajaran yang digunakan oleh guru dalam proses pembelajaran. Proses pembelajaran TIK masih dominan menggunkan metode pembelajaran ceramah, dimana proses pembelajaran terpusat pada guru.

Berdasarkan berbagai permasalahan di atas, penelitian ini difokuskan pada upaya untuk mengatasi masalah yang diduga menjadi penyebab rendahnya hasil belajar TIK siswa kelas XII SMAN $1 \mathrm{X}$ Koto Singkarak dalam menggunakan pendekatan pembelajaran sehingga kegiatan pembelajaran tidak monoton dan membosankan. Untuk itu perlu penerapan metode pembelajaran yang tepat sehingga dapat memperbaiki kuliatas dan hasil belajar yang lebih baik. Salah satu strategi pembelajaran yang diduga mampu mewujudkan situasi pembelajaran yang kondusif, kreatif, efektif, dan menyenangkan adalah metode tutor sebaya. Melalui startegi tutor sebaya, siswa bukan dijadikan sebagai objek pembelajaran tetapi menjadi subjek pembelajaran, namun siswa diajak untuk menjadi tutor atau sumber belajar dan tempat bertanya bagi temannya (Khotimah \& Yuliastuti, 2019). Dalam strategi tutor sebaya guru perlu menerapkan metode pembelajaran yang memperhatikan perbedaan individual siswa dalam belajar (Yusup \& Sari, 2020). Guru dalam memillih metode pembelajaran perlu mempertimbangkan perbedaan individual siswa atau karakteristik siswa, salah satu karakter siswa yang perlu diperhatikan dalam memilih dan menetapkan metode pembelajaran adalah motivasi siswa. Motivasi sangat berhubungan dengan minat siswa dalam belajar yang dapat mempengaruhi prestasi belajarnya. Proses pembelajaran menuntut guru untuk dapat memahami dan mengetahui motivasi siswa, kemudian memilih dan menetapkan metode yang tepat dan sesuai.

Temuan penelitian terdahulu terkait penerapan metode pembelajaran tutor sebaya dan motivasi terhadap hasil belajar yaitu penerapan metode pembelajaran tutor sebaya (peer teaching) pada siswa anak berkebutuhan khusus (ABK) dapat meningkatkan kemampuan komunikasi siswa, interaksi sosial, kolaboratif, keterampilan berpikir kritis, keterampilan motorik, dan meningkatkan motivasi belajar siswa serta untuk meningkatkan hasil belajar siswa dalam aspek kognitif, afektif, dan psikomotorik (April \& Soenyoto, 2018). Melalui model pembelajaran tutor sebaya memberikan pengaruh terhadap hasil belajar matematika siswa. Penerapan model tutor sebaya menyebabkan peserta didik lebih aktif berdiskusi sehingga kemampuan dalam memecahkan masalah menjadi lebih baik (Mahsup et al., 2020). Model tutor sebaya menjadi salah satu inovasi pembelajaran yang dapat meningkatkan kerjasama siswa pada aspek kognitif, aspek afektif dan aspek keterampilan diharapkan akan terjadi peningkatan kemampuan kolaboratif dan komunikatif peserta didik (Nurlizawati, 2019). Oleh itu metode tutor sebaya diharapkan dapat meningkatkan hasil belajar siswa. Sehingga perlu dilakukan penelitian tentang pengaruh penerapan metode pembelajaran tutor sebaya dan motivasi terhadap hasil belajar Teknologi Informasi dan Komunikasi siswa kelas XII SMAN I X Koto Singkarak.

\section{Metode}

Jenis penelitian ini adalah eksperimen semu (quasi experiment) yakni cara penelitian yang dilakukan untuk membandingkan hasil kegiatan dua kelompok yaitu kelompok eksperimen dengan kelompok kontrol melalui perlakuan berbeda. Kelompok eksperimen diberikan perlakuan dengan pembelajaran menggunakan strategi pembelajaran tutor sebaya dan kelompok kontrol dilakukan pembelajaran secara konvensional. Desain penelitian yang digunakan adalah desain faktorial $2 \times 2$. Desain ini diterapkan pada situasi belajar yang 
berbeda, yaitu pembelajaran dengan menggunakan metode tutor sebaya pada kelas eksperimen dan menerapkan pembelajaran konvensional pada kelas kontrol. Hasil belajar dilihat dari tingkat motivasi belajar tinggi dan motivasi belajar rendah. Dalam pelaksanaan penelitian ini kelas ekpserimen diberikan perlakuan dengan menggunakan strategi pembelajaran tutor sebaya dan kelas kontrol pembelajaran dilakukan secara konvensional. Strategi tutor sebaya adalah strategi pembelajaran yang menekankan pada bimbingan dalam memahami pelajaran, dibimbing oleh seorang atau lebih siswa yang memiliki kemampuan lebih tinggi kepada siswa lain yang merupakan teman sekelas atau teman sebangku. Sedangkan pembelajaran konvensional adalah pembelajaran yang menekankan proses bimbingan untuk memahami pelajaran yang dilakukan oleh guru. Perlakuan dilakukan sekitar 7 kali pertemuan dengan masing-masing pertemuan 2 jam pelajaran ( $2 \times 45$ menit). Masingmasing kelompok perlakuan dibuatkan desain pembelajaran yang sama, kecuali pada metode yang digunakan. Kelompok /kelas eksperimen menggunakan strategi pembelajaran dengan tutor sebaya dan kelas kontrol pembelajarannya secara konvensional yang dilakukan oleh guru.

\section{Hasil dan Pembahasan}

Hasil data yang diperoleh dalam penelitian ini berupa hasil studi lapangan untuk memperoleh data hasil belajar dan motivasi belajar siswa dimana satu kelas diajar dengan menggunakan metode pembelajaran tutor sebaya (kelas eksperimen) sedangkan satu kelas lainnya diajar dengan metode ceramah (kelas kontrol).nUji hipotesis yang digunakan pada penelitian ini adalah uji anova 2 arah. Pengujian hipotesis dilakukan dengan cara membandingkan nilai $F_{\text {hitung }}$ dengan $F_{\text {tabel }}$ atau signifikansi dengan alpha $(0,05)$. Berdasarkan hasil nalisis inferensial pada lampiran 18 diperoleh hasil seperti Tabel 1.

Tabel 1. Hasil Uji Hipotesis

\begin{tabular}{cccccc}
\hline Source & $\begin{array}{c}\text { Type III Sum of } \\
\text { Squares }\end{array}$ & df & Mean Square & F & Sig. \\
\hline Corrected Model & $858.727^{\mathrm{a}}$ & 3 & 286.242 & 4.989 & .004 \\
Intercept & 373405.916 & 1 & 373405.916 & $6.508 \mathrm{E} 3$ & .000 \\
Metode & 515.736 & 1 & 515.736 & 8.988 & .004 \\
Pembelajaran & 275.458 & 1 & 275.458 & 4.801 & .032 \\
Motivasi Belajar & & & & & .390 \\
$\quad$ Metode & 43.107 & 1 & 43.107 & & \\
Pembelajaran * & 3327.987 & 58 & 57.379 & & \\
Motivasi Belajar & 379344.547 & 62 & & & \\
$\quad$ Error & 4186.714 & 61 & & & \\
Total & & & & & \\
Corrected Total & & & & & \\
\hline
\end{tabular}

a. R Squared = ,205 (Adjusted R Squared $=, 164$ )

Berdasarkan Tabel hasil uji hipotesisi di atas dapat ditarik kesimpulan untuk menjawab hipotesis penelitian. Pertama, perbedaan hasil belajar TIK siswa yang diajar menggunakan metode tutor sebaya dengan siswa yang diajar menggunakan metode ceramah. Berdasarkan hasil analisis uji hipotesis diketahui metode belajar memiliki nilai $F_{\text {hitung }}$ sebesar 8,988 dan signifikansi sebesar 0,004. Hasil analisis menunjukkan bahwa nilai Sig $(0,004)<$ $(0,05)$, sehingga $\mathrm{H}_{01}$ ditolak dan $\mathrm{Ha}_{1}$ diterima. Dapat disimpulkan bahwa terdapat perbedaan yang signifikan antara hasil belajar TIK siswa yang diajar dengan metode tutor sebaya dengan dengan siswa yang diajar menggunakan metode ceramah. 
Kedua, perbedaan hasil belajar TIK siswa yang memiliki motivasi belajar tinggi dengan siswa yang memiliki motivasi belajar rendah. Berdasarkan hasil analisis uji hipotesis

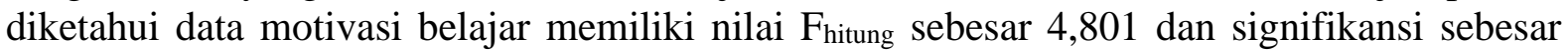
0,032. Hasil analisis menunjukkan bahwa nilai Sig $(0,032)<(0,05)$, sehingga $\mathrm{H}_{02}$ ditolak dan $\mathrm{Ha}_{2}$ diterima. Dapat disimpulkan bahwa terdapat perbedaan yang signifikan antara hasil belajar TIK siswa yang memiliki motivasi belajar tinggi dengan dengan siswa memiliki motivasi belajar rendah. Ketiga, interksi antara startegi pembelajaran dengan motivasi belajar dalam mempengaruhi hasil belajar siswa. Berdasarkan hasil analisis uji hipotesis diketahui hasil interaksi antara metode pembelajaran dengan motivasi belajar dalam mempengaruhi hasil belajar TIK memiliki nilai $F_{\text {hitung }}$ sebesar 0,751 dan signifikansi sebesar 0,390. Hasil analisis menunjukkan bahwa nilai Sig $(0,39)>(0,05)$, sehingga $\mathrm{H}_{03}$ diterima dan $\mathrm{Ha}_{3}$ ditolak. Dapat disimpulkan bahwa tidak terdapat interaksi antara metode pembelajaran dengan motivasi belajar dalam mempengaruhi hasil belajar TIK.

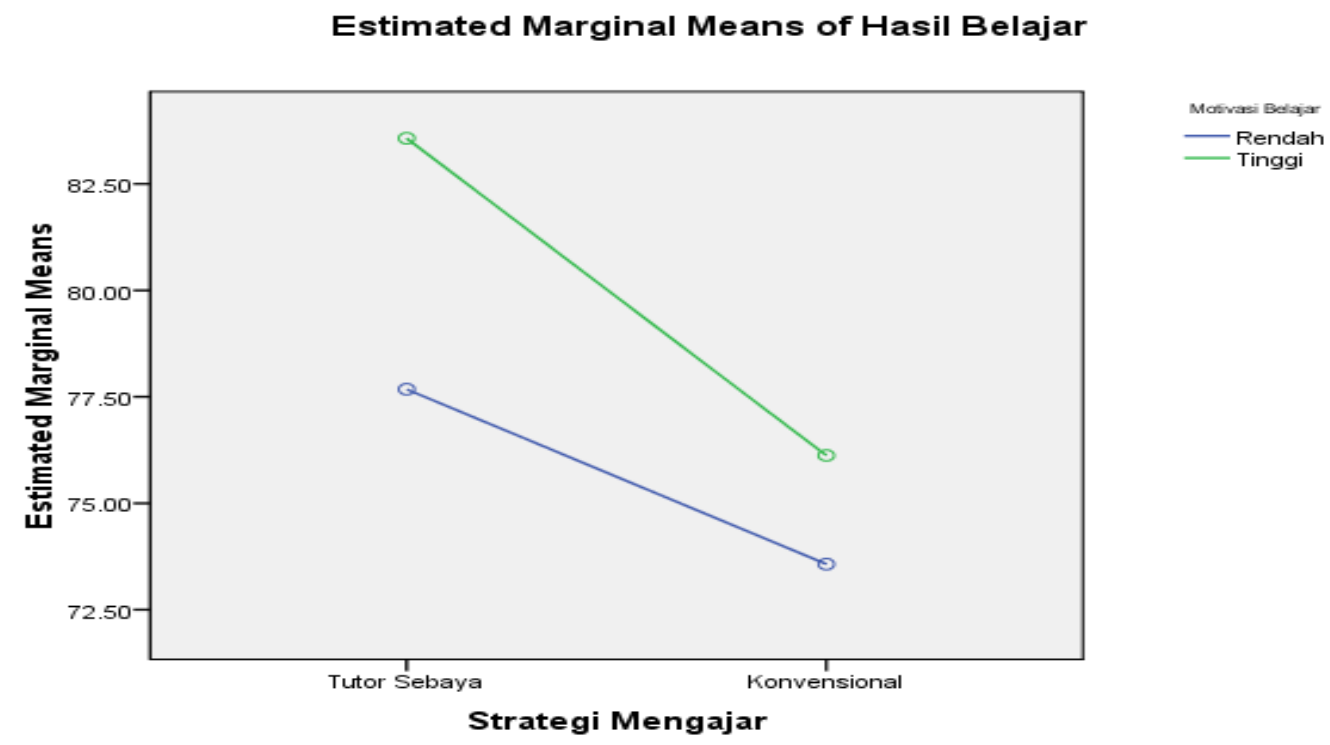

Gambar 1. Grafik Interakasi Metode Pembelajaran dengan Motivasi Belajar terhadap Hasil Belajar.

Gambar grafik di atas jelas memperlihatkan bahwa tidak ada interaksi antara metode pembelajaran dengan motivasi belajar dalam mempengaruhi hasi belajar TIK siswa. Grafik di atas juga mengambarkan bahwa pada kelas eksperimen yang diajar dengan metode tutor sebaya, siswa dengan motivasi belajar yang tinggi memiliki rata-rata hasil belajar yang lebih tinggi dibanding siswa yang motivasi belajarnya rendah. Hal yang sama juga berlaku bagi siswa di kelas kontrol, dimana siswa dengan motivasi belajar yang tinggi memiliki rata-rata hasil belajar yang lebih tinggi dibanding siswa yang motivasi belajarnya rendah. Berdasarkan hasil pengujian hipotesis pertama yang telah dilakukan, diketahui bahwa terdapat perbedaan hasil belajar yang signifikan antara siswa yang diajar dengan metode tutor sebaya dibandingkan yang di ajar dengan metode ceramah. Perbedaan hasil belajar antara siswa kelas eksperimen dan kelas kontrol terlihat dari nilai rata-rata hasil post test kedua kelas. Dapat disimpulkan hasil belajar yang diperoleh oleh siswa kelas eksperimen yang diajar dengan metode tutor sebaya lebih tinggi dari pada hasil belajar siswa kelas kontrol yang diajar dengan metode ceramah.

Hal ini disebabkan karena penerapan metode tutor sebaya membuat siswa lebih aktif dalam proses pembelajaran sehingga dapat memperoleh pemahaman materi dan hasil belajar 
yang lebih baik. Subyek atau tenaga yang memberikan bimbingan dalam kegiatan tutorial dikenal sebagai tutor. Pada penelitian ini yang menjadi tutor adalah siswa, yang dirasa mampu secara akademik dan sikap untuk menjadi tutor. Bantuan belajar oleh teman sebaya dapat menghilangkan kecanggungan (April \& Soenyoto, 2018). Bahasa teman sebaya lebih mudah dipahami, selain itu dengan teman sebaya tidak ada rasa enggan, rendah diri, malu, dan sebagainya, sehingga diharapkan siswa yang kurang paham tidak segan-segan untuk mengungkapkan kesulitan-kesulitan yang dihadapinya (Fadhilah \& Mukhlis, 2021).

Proses pembelajaran menggunakan metode metode ceramah, sebagian siswa kurang aktif dalam proses pembelajaran yang mengakibatkan siswa cepat bosan dan tidak bersemangat dalam mengikuti proses pembelajaran. Metode pembelajaran ceramah dapat dikatakan adalah metode satu arah yang berpusat pada guru, sehingga metode ini menjadikan guru lebih aktif dalam proses pembelajaran (Amri, 2018). Sedangkan kelas yang menggunakan metode tutor sebaya siswa lebih aktif dalam berdiskusi, jika siswa tidak paham langsung bertanya dengan ketua tim, semangat jika ditunjuk untuk mengerjakan dipapan tulis, catatan rapih dan lengkap, banyak pertanyaan yang diajukan ke ketua tim, aktifitas banyak didalam kelas terbukti tidak ada yang mondar-mandir keluar kelas. Sehingga memotivasi mereka untuk meningkatkan hasil belajar. Sikap siswa saat pembelajaran menggunakan metode belajar tutor sebaya lebih baik secara siginifikan dengan siswa yang pembelajarannya diterapkan model pembelajaran konvensional (Yusup \& Sari, 2020).

Temuan hasil penelitian ini sesuai dengan temuan penelitian terdahulu menyatakan penerapan metode pembelajaran Tutor Sebaya pada mata pelajaran Desain Grafis dapat meningkatkan keaktifan dan hasil belajar siswa kelas X Multimedia 1. (Hayati, 2017). Selain itu, temuan penerapan metode pembelajaran tutor sebaya dan motivasi terhadap hasil belajar yaitu penerapan metode pembelajaran tutor sebaya (peer teaching) pada siswa anak berkebutuhan khusus (ABK) dapat meningkatkan kemampuan komunikasi siswa, interaksi sosial, kolaboratif, keterampilan berpikir kritis, keterampilan motorik, dan meningkatkan motivasi belajar siswa serta untuk meningkatkan hasil belajar siswa dalam aspek kognitif, afektif, dan psikomotorik (April \& Soenyoto, 2018). Berdasarkan hasil pengujian hipotesis kedua, diketahui bahwa terdapat perbedaan hasil belajar yang signifikan antara siswa yang diajar memiliki motivasi tinggi dibandingkan dengan yang memiliki motivasi rendah. Perbedaan hasil belajar antara siswa yang memiliki motivasi belajar tinggi dengan siswa yang memiliki motivasi belajar rendah terlihat dari nilai rata-rata hasil post test kedua kelompok. Dapat disimpulkan bahwa nilai rata-rata hasil post test kelompok siswa dengan motivasi belajar terbukti tinggi lebih tinggi dari pada nilai rata-rata hasil post test kelompok siswa dengan motivasi belajar rendah.

Selain itu, dilihat dari dorongan kekuatan mental saat siswa belajar. Kekuatan mental berupa keinginan, perhatian, kemauan, atau cita-cita. Kekuatan mental yang mendorong terjadinya belajar seorang siswa disebut sebagai motivasi belajar. Dalam motivasi terkandung adanya keinginan yang mengaktifkan, menggerakkan, dan mengarahkan sikap dan prilaku individu belajar. Motivasi merupakan segala bentuk dorongan, keinginan individu dan usaha berinteraksi dengan objek (Susmiati, 2020). Dalam mata pelajaran Teknologi Informasi dan Komunikasi, motivasi ini merupakan energi pendorong dalam diri seseorang siswa untuk melakukan aktivitas belajar sampai mencapai tujuan tertentu. Dorongan yang ada dalam diri siswa harus diransang oleh guru untuk berkeinginan meraih keberhasilan dalam belajar dan selalu melibatkan diri dalam kegiatan pembelajaran sehingga mencapai apa yang diinginkan.

Temuan penelitian ini sesuai dengan hasil penelitian terdahulu yang menemukan bahwa siswa dengan motivasi belajar yang tinggi akan mendapat hasil belajar yang lebih baik dari pada siswa dengan motivasi belajar yang rendah. Tinggi rendahnya motivasi selalu dijadikan indikator terhadap baik buruknya prestasi belajar peserta didik. Anak didik yang menyukai mata pelajaran tertentu akan senang mengikuti dan dengan penuh semangat 
mempelajarinya. Motivasi akan menentukan tinggi rendahnya pencapaian prestasi peserta didik (Saptono, 2016). Berdasarkan hasil pengujian hipotesis ketiga, diperoleh hasil tidak terdapat interksi antar startegi pembelajaran dengan motivasi belajar dalam mempengaruhi hasil belajar siswa. Hasil penelitian menunjukkan bahwa metode pembelajaran dan motivasi belajar bukanlah dua buah variabel bebas yang dapat secara bersama-sama mempengaruhi hasil belajar TIK siswa kelas XII SMAN I X Koto Singkarak. Metode mengajar dan motivasi belajar hanya dapat mempengaruhi hasil belajar TIK siswa kelas XII SMAN I X Koto Singkarak secara signifikan secara individu atau parsial. Hal ini menunjukkan hasil belajar siswa dipengaruhi metode mengajar dan motivasi belajar. Tutor sebaya pada dasarnya sama dengan program bimbingan yang bertujuan memberikan bantuan kepada siswa atau peserta didik agar dapat mencapai hasil belajar optimal. Metode tutor sebaya bersifat kooperatif, siswa yang menjadi tutor membantu dan membimbing teman yang belum paham mengenai matei yang belum dipahami, sehingga hasil belajar siswa secara keseluruhan meningkat. Penggunaan metode Tutor Sebaya terbukti mampu menghilangkan kejenuhan siswa, meningkatkan kehadiran siswa, dan motivasi belajar siswa dibandingkan menggunakan metode konvensional.

Dalam mata pelajaran Teknologi Informasi dan Komunikasi, motivasi merupakan energi pendorong dalam diri seseorang untuk melakukan aktivitas belajar untuk mencapai tujuan tertentu. Dorongan yang ada dalam diri siswa harus dirangsang oleh guru untuk berkeinginan meraih keberhasilan dalam belajar dan selalu melibatkan diri dalam kegiatan pembelajaran sehingga mencapai apa yang diinginkan (Syachtiyani \& Trisnawati, 2021). Pemilihan seorang siswa menjadi tutor dalam kelompok belajarnya menjadi kunci keberhasilan pelaksanaan tutor sebaya. Dikarenakan siswa yang menjadi tutor bisa menjadi motivator bagi rekanya atau sebaliknya. Hal ini dikarenakan tidak semua siswa yang terpilih menjadi tutor memiliki kemampuan yang sama dalam menerangkan pelajaran kepada temannya. Selain itu, ketepatan penempatan tutor dengan kelompok atau pasangannya juga bisa menjadi faktor yang mempengaruhi motivasi siswa, karena tidak semua siswa memiliki ikatan pertemanan yang sama. Kondisi inilah yang dirasa menjadi penyebab tidak terjadinya interaksi antara penerapan metode tutor sebaya dengan motivasi belajar siswa.

Sejalan dengan temuan penelitian terdahulu menemukan penerapan model tutor sebaya menyebabkan peserta didik lebih aktif berdiskusi sehingga kemampuan dalam memecahkan masalah menjadi lebih baik (Mahsup et al., 2020). Model tutor sebaya menjadi salah satu inovasi pembelajaran yang dapat meningkatkan kerjasama siswa pada aspek kognitif, aspek afektif dan aspek keterampilan diharapkan akan terjadi peningkatan kemampuan kolaboratif dan komunikatif peserta didik (Nurlizawati, 2019). Metode tutor sebaya yang diterapkan diharapkan dapat memberikan motivasi belajar siswa dengan baik sehingga dapat meningkatkan hasil belajar siswa. Penerapan metode tutor sebaya sudah baik diterapkan pada mata pelajaran teknologi informasi dan komunikasi, namun dalam penerapan metode ini masih memiliki kekurangan yaitu pemilihan tutor, siswa yang memiliki kemampuan akademik tinggi, tidak otomatis menjadi tutor, karena harus mempertimbangkan kemampuan membimbing dan memimpin siswa-siwa lainnya. Selain itu membutuhkan waktu yang cukup lama karena banyak langkah yang harus diterapkan.

\section{Simpulan}

Berdasarkan hasil penelitian dan analisis data dapat disimpulkan Metode pembelajaran tutor sebaya pada mata pelajaran Teknologi Informasi dan Komunikasi (TIK) memberikan hasil yang positif terhadap hasil belajar siswa dibandingkan metode ceramah. Dengan metode pembelajaran tutor sebaya dapat memperbaiki dan meningkatkan hasil belajar siswa menjadi lebih baik. Hal ini menunjukkan bahwa metode pembelajaran tutor 
sebaya cocok digunakan pada mata pelajaran TIK terutama pada siswa yang memiliki motivasi belajar tinggi sehingga mendorong siswa dapat lebih berperan aktif dalam pemelajaran sehingga juga dapat memperbaiki meningkatkan hasil belajar menjadi lebih baik. Penerapan metode pembelajaran tutor sebaya merupakan metode yang digunakan guru untuk memperoleh hasil belajar yang lebih baik dalam proses pmbelajaran karena pemebelajaran lebih interaktif dan siswa senantiasa terdorong untuk beraktivitas dan berkreativitas karena mereka mendapat tantangan untuk lebih bertanggungjawab. Siswa yang memiliki motivasi belajar yang lebih tinggi lebih cenderung memperoleh hasil belajar yang lebih baik pula dibandingkan dengan siswa yang memiliki motivasi belajar rendah. Metode pembelajaran tutor sebaya dan motivasi siswa mempunyai pengaruh secara langsung terhadap peningkatan hasil belajar siswa namun keduanya menunjukkan bahwa tidak terdapat interaksi antara metode pembelajaran tutor sebaya dengan motivasi siswa dalam mempengaruhi hasil belajar siswa.

\section{Daftar Rujukan}

Aka, K. A. (2017). Pemanfaatan Teknologi Informasi dan Komunikasi (TIK) sebagai Wujud Inovasi Sumber Belajar di Sekolah Dasar. Jurnal Pendidikan Dan Pembelajaran Sekolah Dasar, 1(2), 28-37. http://journal.umsurabaya.ac.id/index.php/pgsd/article/view/1041/724.

Amri, N. U. (2018). Perbedaan Hasil Belajar Siswa dengan Pembelajaran Berbasis Masalah dan Pembelajaran Ceramah pada Materi Barisan Aritmatika. Jurnal Pendidikan Matematika RAFA, 4(2), 123-132. https://doi.org/10.19109/jpmrafa.v4i2.2774.

April, V. N., \& Soenyoto, T. (2018). Pengaruh metode pembelajaran tutor sebaya terhadap hasil belajar dribbling sepakbola pada anak berkebutuhan khusus (ABK) The. Journal of Physical Education, $1(1), \quad 15$. https://journal.unesa.ac.id/index.php/bimaloka/article/view/10544/4637.

Fadhilah, N., \& Mukhlis, A. M. A. (2021). Hubungan Lingkungan Keluarga, Interaksi Teman Sebaya Dan Kecerdasan Emosional Dengan Hasil Belajar Siswa. Jurnal Pendidikan, 22(1), 16-34. https://doi.org/10.33830/jp.v22i1.940.2021.

Hayati, I. (2017). Pengaruh Model Pembelajaran Peer Teaching Terhadap Peningkatan Aspek Afektif Mahasiswa pada Mata Kuliah Akuntansi Keuangan Program Studi Perbankan Syariah Universitas Muhammadiyah Sumatera Utara. Jurnal Ekonomi Dan Perbankan Syariah, 2(2). https://doi.org/10.30651/jms.v2i2.1133.

Khotimah, K., \& Yuliastuti, R. (2019). Penerapan Model Pembelajaran Tuntas dengan Metode Tutor Sebaya untuk Meningkatkan Hasil Belajar Matematika Siswa SMP. Edumatika: Jurnal Riset Pendidikan Matematika, 2(2), 77. https://doi.org/10.32939/ejrpm.v2i2.301.

Kurniawan, A. (2019). Utilization of Information and Communication Technologies ( ICT ) for Learning in SMPN 5 Ponorogo , East Java. Jurnal Teknodik, 23(1), 55-64. https://doi.org/10.32550/teknodik.v0i0.369.

Lestari, A. W., Mangesa, R. T., \& -, M.-. (2020). Penerapan Tutor Sebaya Dalam Implementasi Strategi CIRC Berbasis Active Learning Untuk Meningkatkan Hasil Belajar Siswa Pada Mata Pelajaran Sistem Komputer di SMKN 5 Makassar. Jurnal MediaTIK, 3(3), 13. https://doi.org/10.26858/jmtik.v3i3.15174.

Mahsup, Ibrahim, Muhardini, S., Nurjannah, \& Eka Fitriani. (2020). Peningkatan Hasil Belajar Mahasiswa Melalui Model Pembelajaran Tutor Sebaya. Jurnal Kependidikan, 6(3), 609-616. https://doi.org/10.33394/jk.v6i3.2673.

Nurlizawati. (2019). Penerapan Model Pembelajaran Tutor Teman Sebaya Di SMAN 1 Pasaman. Journal of Sociology Research and Education, 6(1), 951-952. https://doi.org/10.24036/scs.v6i1.127. 
Patmanthara, S. (2018). Pemanfaatan Teknologi Informasi Dan Komunikasi Untuk Pengembangan Pembelajaran Melalui Web Sekolah. Jurnal Teknodik, 10(19), 056. https://doi.org/10.32550/teknodik.v10i19.393.

Rivalina, R. (2014). Kompetensi Teknologi Informasi Dan Komunikasi Guru Dalam Peningkatan Kualitas Pembelajaran. Jurnal Teknodik, 18(2), 165-176.

Saptono, Y. J. (2016). Motivasi dan Keberhasilan Belajar Siswa. Jurnal Pendidikan Agama Kristen, $\quad 1(1), \quad$ 189-212. http://christianeducation.id/ejournal/index.php/regulafidei/article/view/9.

Susmiati, E. (2020). Meningkatkan Motivasi Belajar Bahasa Indonesia Melalui Penerapan Model Discovery Learning dan Media Video Dalam Kondisi Pandemi Covid-19 bagi Siswa SMPN 2 Gangga. Jurnal Penelitian Dan Pengembangan Pendidikan, 7(3), 210-215. https://doi.org/10.33394/jp.v7i3.2732.

Syachtiyani, W. R., \& Trisnawati, N. (2021). Analisis Motivasi Belajar Dan Hasil Belajar Siswa Di Masa Pandemi Covid-19. Prima Magistra: Jurnal Ilmiah Kependidikan, 2(1), 90-101. https://doi.org/10.37478/jpm.v2i1.878.

Wendi, D. (2020). The 2013 Curriculum Implementation Review The Pedagogical Competence And Mastery Of Information And Communication Technology Teachers At SD Negeri. Pedagogi: Jurnal Ilmu Pendidikan, 20(2), 128-134. https://doi.org/10.24036/pedagogi.v20i2.881.

Yusup, A. A. M., \& Sari, A. I. C. (2020). Penerapan Metode Pembelajaran Peer Teaching Untuk Meningkatkan Hasil Belajar Mata Kuliah Kalkulus. Research and Development Journal of Education, 6(2), 01. https://doi.org/10.30998/rdje.v6i2.5457. 